Scientia Marina 71(2)

June 2007, 293-304, Barcelona (Spain)

ISSN: 0214-8358

\title{
Assessment of spatial environmental quality status in Ria de Aveiro (Portugal)
}

\author{
CLÁUDIA BATISTA LOPES ${ }^{1}$, MARIA EDUARDA PEREIRA ${ }^{1}$, CARLOS VALE $^{2}$, ANA $^{2}$ \\ ISABEL LILLEB $\emptyset^{1}$, MIGUEL ÂNGELO PARDAL ${ }^{3}$ and ARMANDO COSTA DUARTE ${ }^{1}$ \\ ${ }^{1}$ CESAM - Department of Chemistry, University of Aveiro, Campus de Santiago, 3810-193 Aveiro, Portugal. E-mail: \\ clopes@dq.ua.pt \\ ${ }_{2}^{2}$ INIAP - National Institute of Agronomies and Fisheries Research, Av. Brasília, 1400, Lisboa, Portugal. \\ ${ }^{3}$ IMAR - Institute of Marine Research, Department of Zoology, University of Coimbra, 3004-517 Coimbra, Portugal.
}

SUMMARY: The productivity of Ria de Aveiro is sustained by the large quantities of dissolved inorganic nutrients, mainly from freshwater inputs (e.g. agricultural drainage) and organic-rich anthropogenic point sources (e.g. urban sewage). The concentration of silicate and nitrate showed a similar seasonal variation and conservative behaviour, since 63 to $96 \%$ of the total variance of the concentration of silicate and 88 to $96 \%$ of the total variance of the concentration of nitrate were explained by salinity. On the other hand, the concentration of nitrite, ammonium, and phosphate did not seem dependent on the freshwater inputs, showing a random distribution with salinity. Nutrient concentrations were always higher in the two inner areas than at the outer boundary of the system. Chlorophyll $a$ showed higher concentrations throughout spring and summer, and also in the inner areas. The annual variation of $\mathrm{N}: \mathrm{P}, \mathrm{N}: \mathrm{Si}$ and phytoplankton biomass suggests that there is a large excess of nitrate. The results suggest that within a system with low overall eutrophic condition (OEC) and low susceptibility (US-NEEA index), the quality status of different areas within the system can vary (Applying the EU-WFD criteria proposed for the trophic classification of the Baltic Sea). This work also suggests that in coastal lagoons such as Ria de Aveiro, where the quality status of certain specific areas may vary, these particular areas should be taken under consideration for specific monitoring programmes and management measurements, particularly with regard to anthropogenic point sources.

Keywords: eutrophication, chlorophyll $a$, nitrogen, phosphorous, silicate, estuaries.

RESUMEN: Evaluación de la calidad ambiental en la Ría de Aveiro (Portugal). - La productividad de la Ría de Aveiro está sostenida por grandes cantidades de nutrientes inorgánicos disueltos, procedentes principalmente de aportes de aguas dulces (e.g. de la drenaje agrícola) y por puntos de ricos aportes orgánicos de origen antropogénico (e.g. aguas residuales urbanas). La concentración de silicatos y nitratos mostraron variaciones estacionales similares un comportamiento conservativo, en el que la salinidad explicó del 63 al 96\% de la varianza total de la concentración de silicato y un 88 al $96 \%$ de la varianza total de la concentración nitratos. Al contrario, la concentración de nitrito, amonio, y fosfato no pareció depender de los aportes de agua dulce, mostrando una distribución al azar con la salinidad. Las concentraciones de nutrientes fueron siempre más altas en las dos áreas más internas, cuando se compararon con el límite exterior del sistema. La clorofila a presentó mayores concentraciones a lo largo de la primavera y verano, y fue siempre más alta en las áreas interiores. La variación anual de N:P, N:Si y biomasa de fitoplancton sugieren que hay un gran exceso de nitratos. Los resultados sugieren que dentro de un sistema con una condición eutrófica general baja (OEC) y un bajo índice de susceptibilidad (US-NEEA), el estatus de calidad de las diferentes áreas dentro del sistema puede variar (EU-WFD cuando se aplican criterios utilizados en la clasificación de niveles de nutrientes en aguas de transición y de la condición trófica del mar del Norte). Este trabajo también sugiere que en lagunas costeras como la Ría de Aveiro, donde el estatus de calidad de ciertas áreas puede variar, estas áreas particulares deberían ser tenidas en consideración para programas específicos de control y decisiones sobre medidas de gestión, es decir considerando los puntos de aporte antropogénicos.

Palabras clave: eutrofización, clorofila $a$, nitrógeno, fósforo, silicatos, estuarios. 


\section{INTRODUCTION}

Estuaries are highly complex and very dynamic ecosystems, in which the physical and chemical dynamics are strongly influenced by the freshwater runoff and by the adjacent open sea (Duarte et al., 2001). The freshwater flow influences estuarine hydrology by creating salinity gradients and/or stratification, and maintains a large input of silt, organic material and inorganic nutrients into the estuarine system (Flindt et al., 1999). As transitional areas between land and sea, most estuaries and coastal lagoons receive large amounts of nutrients and pollutants derived from urban, agricultural and industrial effluents (Lillebø et al., 2005; Paerl, 2006). Due to the shallow depth and relatively weak exchange with the open sea, these systems are particularly vulnerable to eutrophication (with the concomitant decline in environmental quality), which is recognised as a major problem worldwide (e.g. Meeuwing, 1999; Flindt et al., 1999; Cloern, 2001; Lillebø et al., 2005).

Over the last few decades, many coastal and marine water bodies have experienced eutrophication, resulting in induced changes in community dominance and species composition (Sand-Jensen and Borum, 1991; Cardoso et al., 2004). Ultimately, these processes may have severe consequences for the biological structure of the systems, involving loss of species diversity (Cardoso et al., 2004) and lower secondary productivity (Dolbeth et al., 2003). Nevertheless, regardless of the high anthropogenic nutrients loading into coastal systems, phytoplankton biomass may be limited by a nutrient due to an alteration in the $\mathrm{N}: \mathrm{P}$ and/or $\mathrm{N}: \mathrm{Si}$ nutrient ratios (Meeuwing, 1999; Yin et al., 2001). Moreover, the same estuarine system may show a spatial and/or seasonal shift from $\mathrm{P}$ to $\mathrm{N}$ limitation, or $\mathrm{N}$ and Si colimitation (Yin et al., 2001). Thus, knowledge of nutrient inputs and their ratios in estuaries - particularly those of growth-limiting nutrients such as nitrogen, phosphorus and silica-is of fundamental importance for assessing environmental quality.

During the last few decades, since conservation and restoration of coastal areas has become a priority, the need for environmental classification tools has emerged. In order to evaluate the trophic status of estuarine systems, several ecological classification tools have been developed and proposed in Europe within the European Water Framework Directive (e.g. Crouzet et al., 1999; Wasmund et

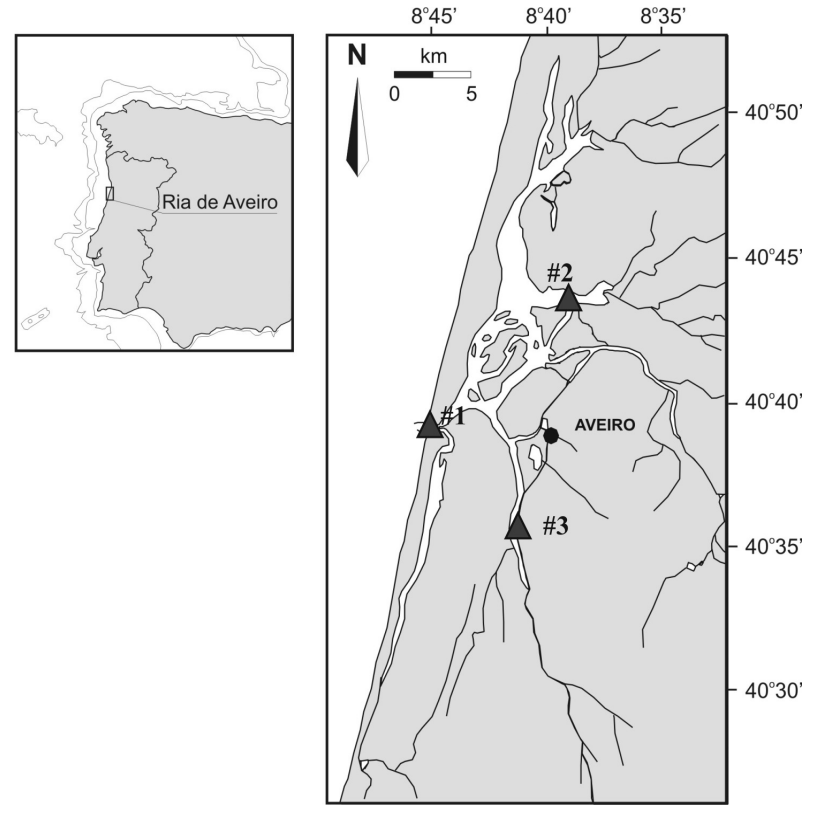

FIG. 1. - Ria de Aveiro with the location of the sampling stations (Station 1 Barra = bar entrance, Station 2 Cais do Chegado and Station 3 Vista Alegre).

$a l ., 2001)$ and in the USA (United States national Estuarine Eutrophication Assessment - NEEA index, Bricker et al., 1999).

The Ria de Aveiro (Fig. 1), situated on the northern coast of Portugal, is of considerable regional importance. It is composed of a wide range of biotopes (e.g. wetlands, salt marshes and mudflats) used as nursery areas for many valuable species that include bivalves, crustaceans, fish and birds. Moreover, from the conservational point of view this system is considered a high priority since it is a fundamental step in the migration of aquatic birds and an ideal place for winter shelter and nesting (Reis, 1993). The whole area of the Ria de Aveiro supports agriculture farms and activities intrinsically associated with major towns in coastal areas: port facilities, industries, aquacultures, saltproduction and fishing.

The objectives of the present study are: a) to assess the seasonal variability of the limiting nutrients (nitrogen, phosphorus and silica) and the linkage between the N:Si and N:P nutrient ratios and the chlorophyll $a$ concentration at the system outer boundary and at two inner stations; b) to classify the environmental quality status at each of these stations by applying two ecological classifications (Crouzet et al., 1999; Wasmund et al., 2001); and c) to assess the nutrient loading at the system level and compare it with that found in previous studies in the Ria (Ferreira et al., 2003) and other systems. In order to 
address these objectives, salinity, temperature, nutrient and chlorophyll $a$ were sampled simultaneously in the inner areas and at the outer boundary of the Ría de Aveiro.

\section{MATERIALS AND METHODS}

\section{Study site}

The Ria de Aveiro is a shallow, "bar-built" estuary that is permanently connected to the ocean by a single open boundary, located on the western coast of Portugal (Fig. 1). The estuary is about $45 \mathrm{~km}$ long (NNE-SSW) and $8.5 \mathrm{~km}$ wide, and the wetland area covers approximately $47 \mathrm{~km}^{2}$ at high tide and $43 \mathrm{~km}^{2}$ at low tide (Barroso et al., 2000). The only connection to the Atlantic Ocean is through a narrow channel $1.3 \mathrm{~km}$ long, $350 \mathrm{~m}$ wide and $20 \mathrm{~m}$ deep. Morphologically, the Ria de Aveiro system consists of a main longitudinal channel and successive ramifications. The mean depth of the lagoon is about $1 \mathrm{~m}$ (the tidal range being 1 to $3 \mathrm{~m}$ ), except in the navigation channels, where dredging operations maintain a depth of about $7 \mathrm{~m}$.

The hydrological circulation is dominated by the water exchange with the ocean due to the low freshwater input $\left(1.8 \times 10^{6} \mathrm{~m}^{3}\right.$ per tidal cycle) compared with the seawater penetrating the system (about $90 \mathrm{x}$ $10^{6} \mathrm{~m}^{3}$ in spring tides) (Moreira et al., 1993). As a consequence of the low freshwater discharge from the tributaries and the diffuse runoff combined with the tidal penetration, the Ria de Aveiro exhibits a spatial gradient of salinity from about 0 in the upper reaches of the estuary to about 36 at the bar entrance. The tidal time delay relative to the bar entrance may reach $6 \mathrm{~h}$ or more in the inner reaches of the channels (Moreira et al., 1993).

\section{Sampling procedure and analysis}

The sampling programme (19 field campaigns during an annual cycle) was carried out at three stations in the Ria de Aveiro, Barra (Station 1), Cais do Chegado (Station 2) and Vista Alegre (Station 3) (Fig. 1), between December 2000 and November 2001. Station 1 is located close to the bar (water depth is about $20 \mathrm{~m}$ ), and therefore has a stronger marine influence, whereas Stations 2 and 3 are located in the inner reaches of the estuary. Additionally, Station 2 is a channel with 2-3 m depth that receives the effluents of an industrial complex, and Station 3 is a channel with 4-5 m depth into which some urban waste waters are still discharged without treatment. Since the Ria de Aveiro is a shallow intertidal system, samples were collected at high tide (HT) and low tide (LT). At each sampling date and station, surface temperature and salinity were measured in situ. Water samples were collected from a depth of about 30 $\mathrm{cm}$ using polyethylene bottles that were rinsed at least twice with surface water before being filled with the samples. Water samples for dissolved inorganic nutrient analyses (ammonium, $\mathrm{NH}_{4}^{+}$; phosphate, $\mathrm{HPO}_{4}^{2-;}$; silicate, $\mathrm{Si}(\mathrm{OH})_{4}$; nitrite, $\mathrm{NO}_{2}^{-}$ and nitrate, $\mathrm{NO}_{3}^{-}$) were immediately filtered through a $0.45 \mu \mathrm{m}$ MSI Acetate plus filter. The filtered water was preserved in PVC bottles by deep freezing at $-20^{\circ} \mathrm{C}$ until analysis, except the filtered water for analysis of $\mathrm{HPO}_{4}{ }^{2-}$, which was preserved in glass bottles at $4^{\circ} \mathrm{C}$. Nutrient analyses were carried out using an Alliance Evolution II autoanalyser according to the Tréguer and Le Corre (1975) methods. For chlorophyll $a(\mathrm{Chl} a)$ determinations, $500-1000 \mathrm{~mL}$ of water was immediately filtered through a $0.45 \mu \mathrm{m}$ Millipore cellulose acetate membrane filter. The filters were extracted in $90 \%(\mathrm{v} / \mathrm{v})$ acetone for at least $12 \mathrm{~h}$ at $4^{\circ} \mathrm{C}$ in the dark and pigments were determined using a Shimadzu UV-2101 PC spectrophotometer according to Parsons et al. (1985).

\section{RESULTS}

Water temperature showed a clear seasonal variation, with a winter minimum and a summer maximum (Fig. 2). Station 1 showed the lowest water temperature range $\left(12.8-19.5^{\circ} \mathrm{C}\right)$ due to the higher depth and seawater influence, while the inner areas showed similar water temperature ranges: 11.2$23.5^{\circ} \mathrm{C}$ at Station 2 and $12.1-23.0^{\circ} \mathrm{C}$ at Station 3. The seasonal variation of salinity was strongly influenced by the variation of precipitation, whose values changed between 0 and $59.0 \mathrm{~mm} / 24 \mathrm{~h}$ during the sampling period (Department of Physics, University of Aveiro, http://www.fis.ua.pt/torre). The highest salinity values were recorded during the warmer/dry periods, when freshwater inputs were lower and high runoff events were negligible (Fig. 2). During the autumn and winter, the considerable increase and predominance of freshwater inputs decreased 

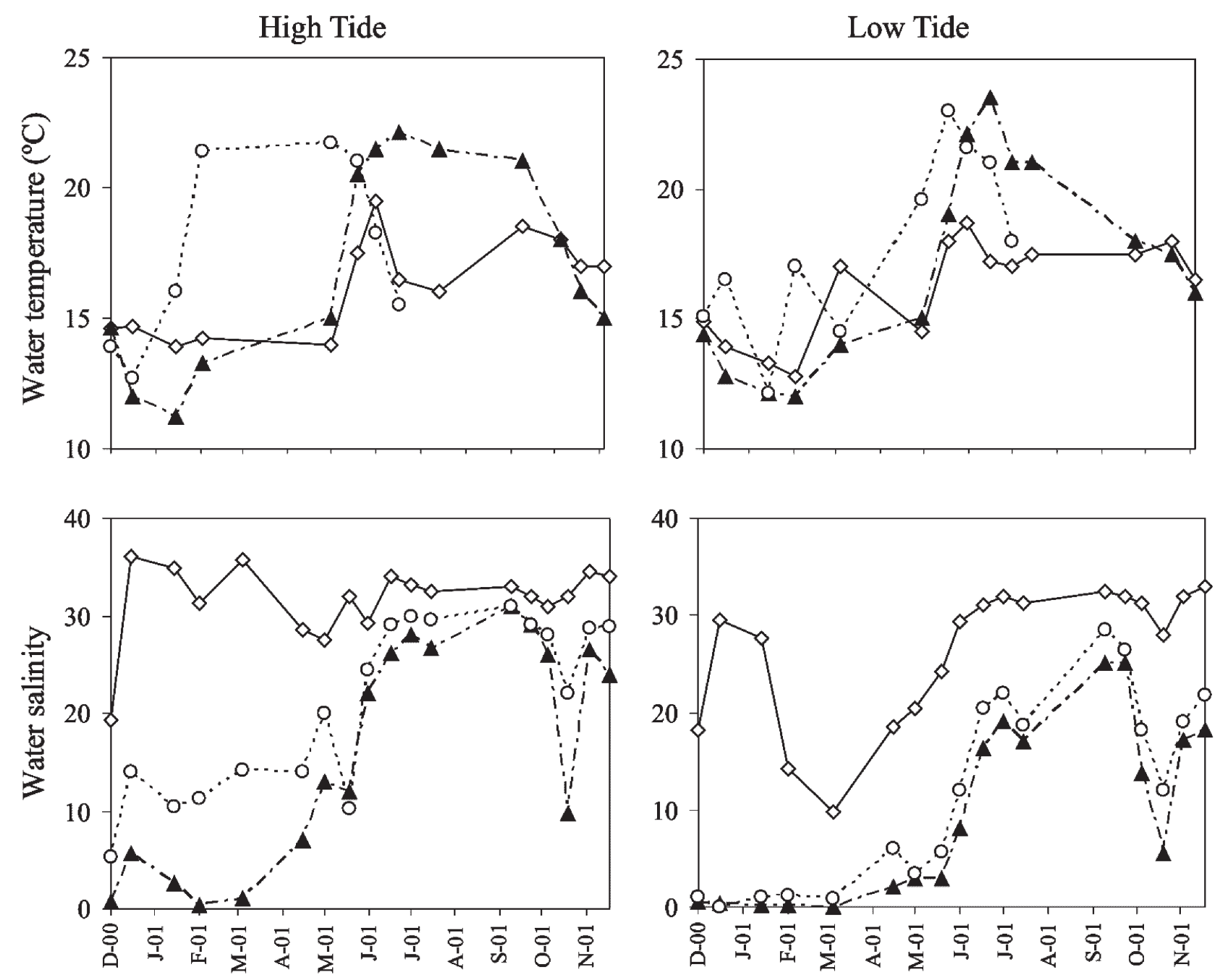

FIG. 2. - Seasonal variation of the temperature $\left({ }^{\circ} \mathrm{C}\right)$ and salinity of surface waters at high and low tide between December 2000 and November 2001 (Station 1: diamonds; Station 2: triangles; Station 3: open circles).

salinity, especially in the inner areas and during low tide. At station 1 this seasonal variation was less pronounced during high tide due to the seawater influence. Salinity varied from 9.8-36.1 at Station 1 and from 0.0-31.0 at Stations 2 and 3.

\section{Spatial and seasonal variation of nutrients}

Nitrate showed a clear seasonal pattern, with higher concentrations in winter and early spring and lower concentrations in summer (Fig. 3). Nitrate was much higher at Stations 2 and 3 (mean concentrations of 51.2 and $42.6 \mu \mathrm{mol} \mathrm{L}^{-1}$ at high tide and of 118 and $85.4 \mu \mathrm{mol} \mathrm{L}^{-1}$ at low tide, respectively) than at Station 1 (mean concentrations of $6.0 \mu \mathrm{mol} \mathrm{L}^{-1}$ at high tide and $15.8 \mu \mathrm{mol} \mathrm{L}^{-1}$ at low tide). Nitrate exhibited a strong inverse linear relationship with salinity at all sampling stations (Fig. 4). Highly sig- nificant correlations were found between nitrate and salinity at Stations 2 and $3(r=-0.96, \mathrm{P}<0.001$, at high tide and $-0.94, \mathrm{P}<0.001$ at low tide at Station 2 and $-0.95, \mathrm{P}<0.001$, for both tides at Station 3$)$. The correlation at Station 1 during high tide was lower $(r$ $=-0.48, P<0.05)$ due to the lower salinity range. However, a highly significant correlation was observed at low tide $(r=-0.98, P<0.001)$. This behaviour reflects a conservative mixing between nitrate-rich river waters and nitrate-poor coastal waters. The linear regression between nitrate and salinity explains between 88 and $96 \%$ of the total variance of nitrate.

The lowest nitrite levels were recorded at Station $1\left(<1.5 \mu \mathrm{mol} \mathrm{L}^{-1}\right)$ for both high and low tides. At Stations 2 and 3, the highest values were found at low tide (mean concentrations of 1.68 and $2.1 \mu \mathrm{mol}$ $\mathrm{L}^{-1}$ at high tide and of 4.4 and $2.9 \mu \mathrm{mol} \mathrm{L}^{-1}$ at low 

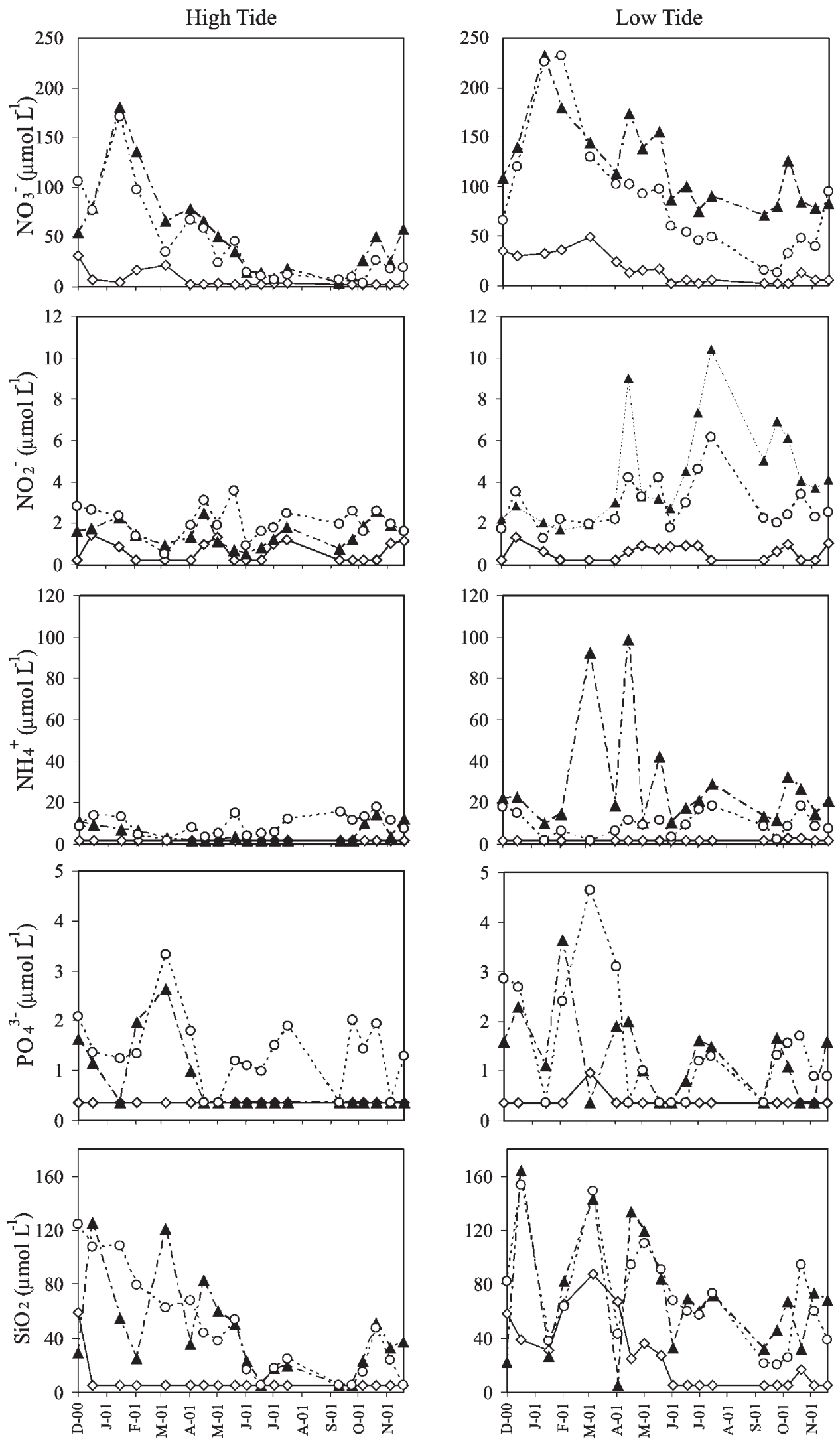

FIG. 3. - Seasonal variation of the nitrate, nitrite, ammonium, phosphate and silicate concentrations $\left(\mu \mathrm{mol} \mathrm{L}^{-1}\right)$ of surface waters at high and low tide between December 2000 and November 2001 (Station 1: diamonds; Station 2: triangles; Station 3: open circles). 

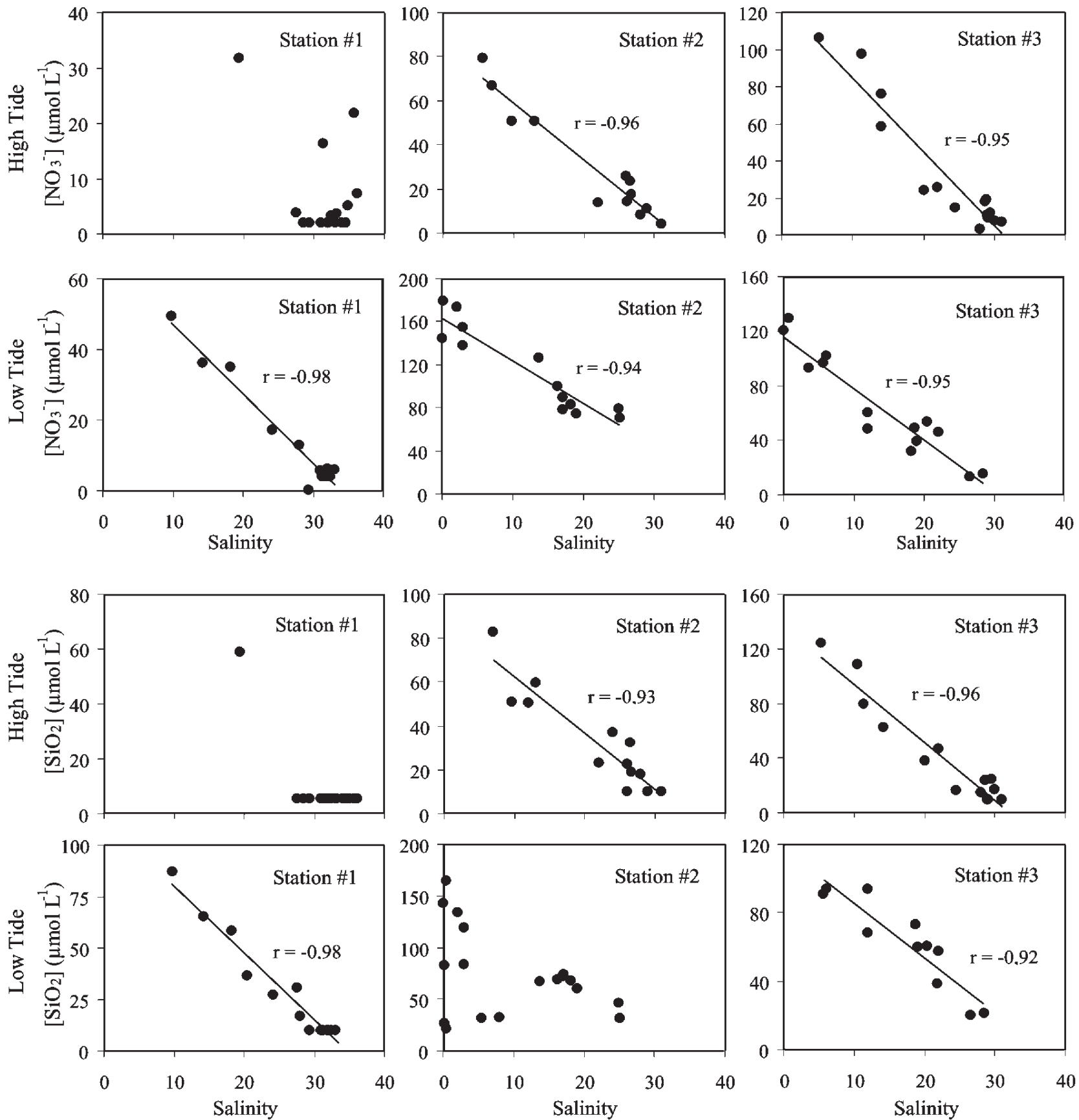

FIG. 4. - Linear relationship between salinity and nitrate $\left(\mu \mathrm{mol} \mathrm{L}^{-1}\right)$ and between salinity and silicate $\left(\mu \mathrm{mol} \mathrm{L}^{-1}\right)$ at Stations 1,2 and 3 at high and at low tide.

TABLE 1. - Regression coefficients of the linear correlation between ammonium $\left(\mu \mathrm{mol} \mathrm{L} \mathrm{L}^{-1}\right)$, nitrite $\left(\mu \mathrm{mol} \mathrm{L} \mathrm{L}^{-1}\right)$, nitrate $\left(\mu \mathrm{mol} \mathrm{L} \mathrm{L}^{-1}\right)$, phosphate $(\mu \mathrm{mol} \mathrm{L}-1)$, silicate $\left(\mu \mathrm{mol} \mathrm{L}^{-1}\right)$ and chlorophyll $a\left(\mu \mathrm{g} \mathrm{L}^{-1}\right)$ with salinity, $*=\mathrm{P}<0.05 ; * *=\mathrm{P}<0.01 ; * * *=\mathrm{P}<0.001$.

\begin{tabular}{|c|c|c|c|c|c|c|c|}
\hline$R$ & & $\mathrm{NH}_{4}^{+}$ & $\mathrm{NO}_{2}^{-}$ & $\mathrm{NO}_{3}^{-}$ & $\mathrm{HPO}_{4}{ }^{2-}$ & $\mathrm{Si}(\mathrm{OH})_{4}$ & Chl $a$ \\
\hline \multirow{2}{*}{ Station 1} & $\mathrm{HT}$ & 0.00 & 0.22 & $-0.48^{*}$ & 0.00 & $-0.79 * * *$ & 0.20 \\
\hline & LT & 0.17 & 0.36 & $-0.98 * * *$ & $-0.58 * * *$ & $-0.98 * * *$ & 0.36 \\
\hline \multirow[t]{2}{*}{ Station 2} & HT & -0.33 & 0.00 & $-0.96 * * *$ & $-0.66 * * *$ & $-0.93 * * *$ & $0.55 * *$ \\
\hline & $\mathrm{LT}$ & -0.36 & $0.82 * * *$ & $-0.94 * * *$ & -0.20 & $-0.40 *$ & 0.00 \\
\hline \multirow[t]{2}{*}{ Station 3} & HT & 0.10 & -0.32 & $-0.95 * * *$ & -0.22 & $-0.96 * * *$ & 0.00 \\
\hline & $\mathrm{LT}$ & 0.00 & 0.14 & $-0.95 * * *$ & $-0.46^{* * *}$ & $-0.92 * * *$ & 0.00 \\
\hline
\end{tabular}


tide, respectively) (Fig. 3). Concentrations were usually higher in spring and summer and lower in autumn and winter. The absence of a significant linear relationship between nitrite and salinity (Table 1) suggests that the freshwater input is not the main source of this nutrient in the Ria de Aveiro.

Throughout the study period, the ammonium concentration rarely exceeded $2.0 \mu \mathrm{mol} \mathrm{L}-1$ at Station 1 but the mean concentrations varied between 4.9 and $9.4 \mu \mathrm{mol} \mathrm{L}^{-1}$ at high tide and between 27.7 and 9.7 $\mu$ mol L $\mathrm{L}^{-1}$ at low tide at Stations 2 and 3, respectively. Ammonium exhibited a random distribution with salinity in both tidal conditions (Table 1).

During the study period, Station 1 always exhibited the lowest phosphate concentrations (mean value $<0.40 \mu \mathrm{mol} \mathrm{L}^{-1}$ ), with no clear seasonal variation and similar concentrations at high and low tides. Mean phosphate concentrations were 0.7 and $1.4 \mu \mathrm{mol} \mathrm{L}^{-1}$ at high tide and 1.3 and $1.5 \mu \mathrm{mol} \mathrm{L}^{-1}$ at low tide at Stations 2 and 3, respectively. The highest phosphate concentrations were recorded in early spring, although a seasonal variation was not clear. Phosphate exhibited a random distribution with salinity in both tidal conditions (Table 1).

Silicate concentrations were much higher at the inner Stations 2 and 3 (mean concentrations of 42.3 and $44.9 \mu \mathrm{mol} \mathrm{L}^{-1}$ at high tide and 70.1 and $70.7 \mu \mathrm{mol}$ $\mathrm{L}^{-1}$ at low tide, respectively) than at Station 1 (mean concentration of $8.4 \mu \mathrm{mol} \mathrm{L}-1$ at high tide and 26.5 $\mu \mathrm{mol} \mathrm{\textrm {L } ^ { - 1 }}$ at low tide). The highest silicate levels were recorded during winter and spring at low tide, while the lower levels were observed in summer and autumn and at high tide (Fig. 3). Silicate showed a behaviour similar to nitrate, characterised by a significant inverse linear relationship with salinity, and therefore a conservative behaviour during estuarine mixing (Fig. 4). The linear regression between silicate and salinity explains between 63 and $96 \%$ of the total variance of silicate. At Stations 1 and 3, a highly significant correlation was found between silicate and salinity $(r=-0.79, P<0.001$ at high tide and $r=-0.98, P<0.001$ at low tide at Station 1 , and $r=-0.96, P<0.001$ at high tide and $r=$ $-0.92, P<0.001$ at low tide at Station 3). At Station 2, a highly significant correlation between the two parameters was observed at high tide $(r=-0.93, P<0.001)$.

\section{Chlorophyll $a$ and N:P and N:Si molar ratios}

Chlorophyll $a$ exhibited a clear seasonal pattern, with lower concentrations in winter and autumn and higher ones throughout spring and summer (Fig. 5).
Spatially, higher concentrations occurred in the inner areas and usually at low tide (mean concentrations of 6.2 and $4.1 \mu \mathrm{g} \mathrm{L}^{-1}$ at high tide and 7.3 and $6.2 \mu \mathrm{g} \mathrm{L}^{-1}$ at low tide at Stations 2 and 3, respectively). At Station 1 , chlorophyll $a$ was lower than in the inner areas and
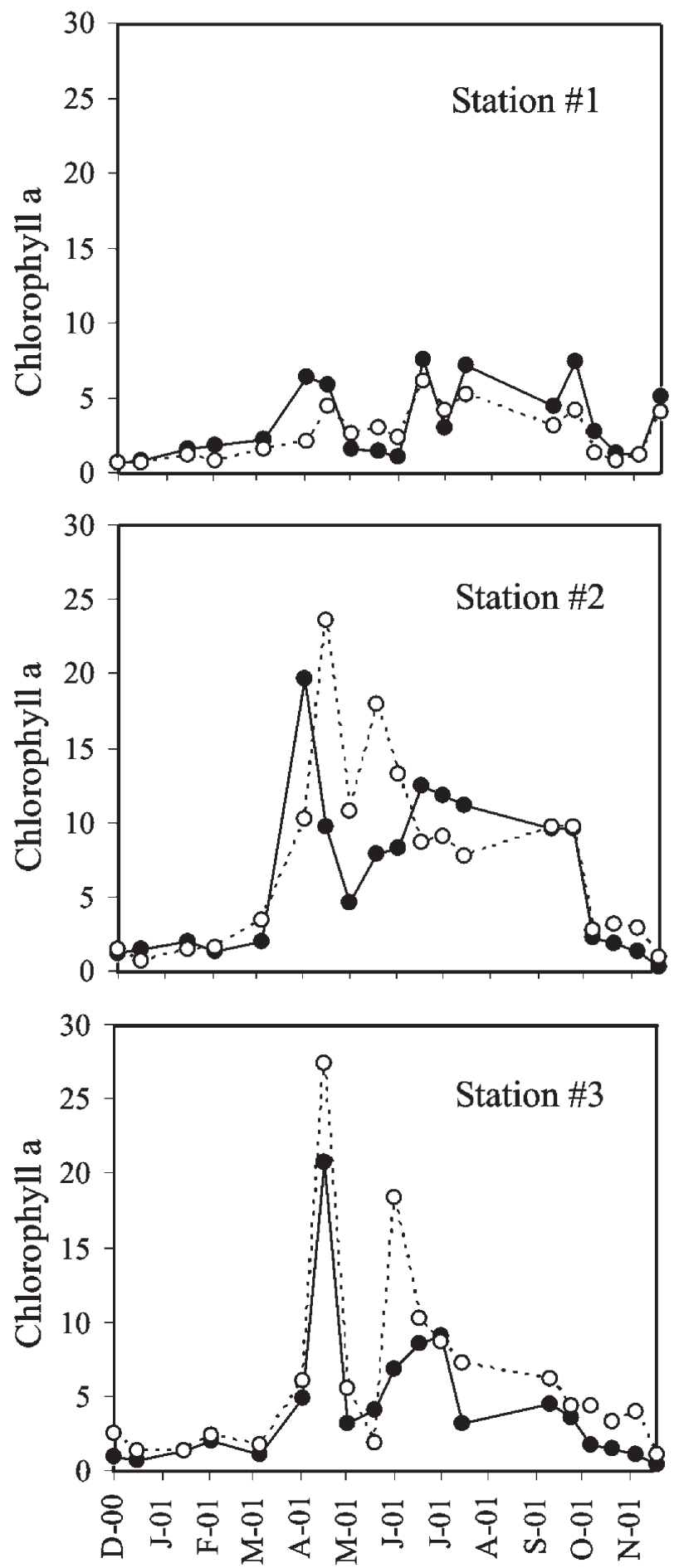

FIG. 5. - Seasonal variation of the chlorophyll $a\left(\mu \mathrm{g} \mathrm{L}^{-1}\right)$ concentration of surface waters at Stations 1,2 and 3 between December 2000 and November 2001 (high tide: full circles; low tide: open circles). 

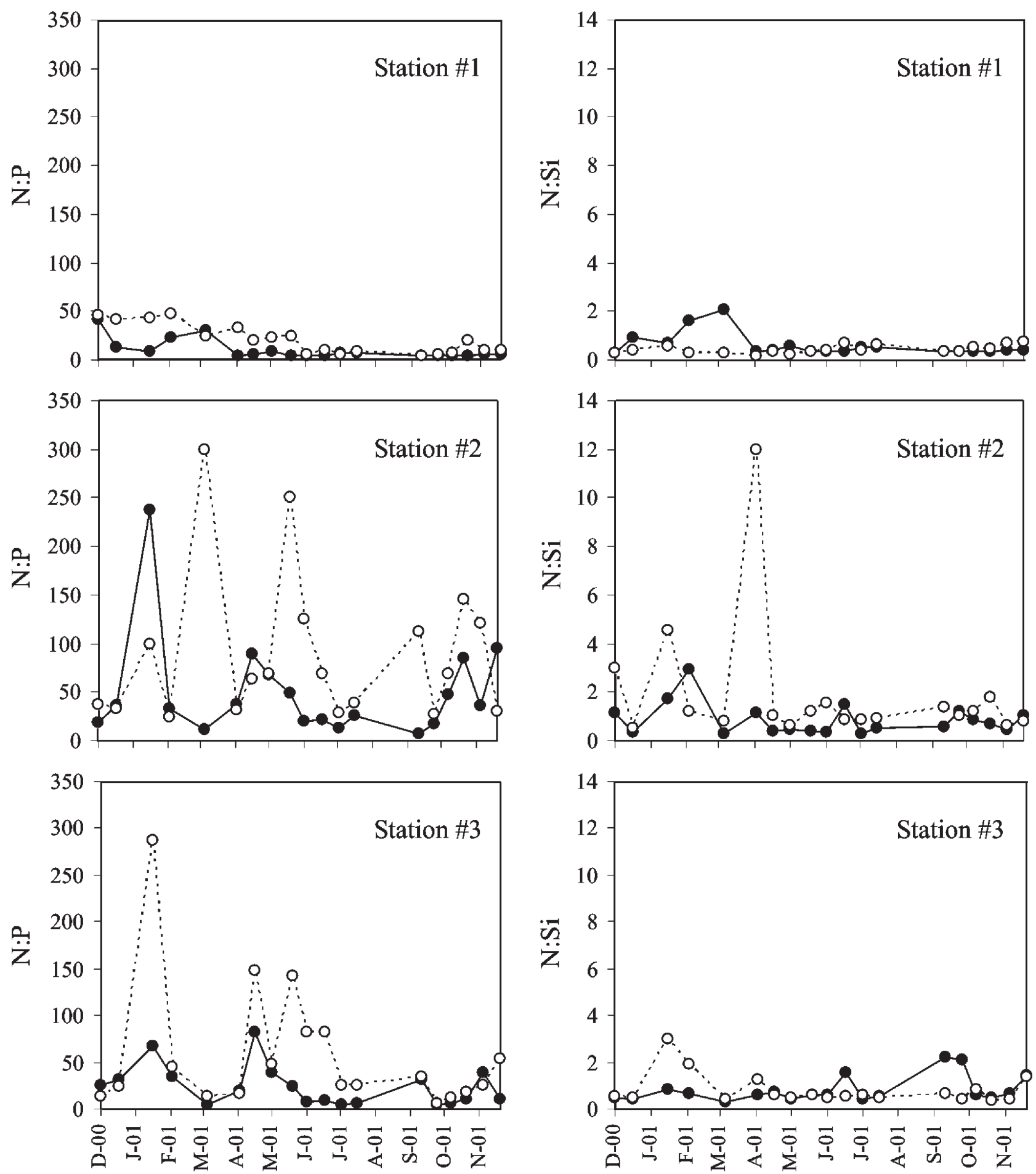

FIG. 6. - Seasonal variation of the N:P and N:Si molar ratios of surface waters at Stations 1, 2 and 3 between December 2000 and November 2001 (high tide: full circles; low tide: open circles).

usually higher at high tide (mean concentrations of 3.3 $\mu \mathrm{g} \mathrm{L}^{-1}$ at high tide and $2.6 \mu \mathrm{g} \mathrm{L}^{-1}$ at low tide). Chlorophyll $a$ showed a random distribution with salinity (Table 1). As expected, the low correlation between these parameters indicates that chlorophyll $a$ changes were mainly influenced by in situ processes.
At Stations 2 and 3, the N:P nutrient ratio showed the highest values in winter and early spring, probably due to the contribution of the nitrate-rich freshwater inputs (Fig. 6). Maximum N:P ratios for Stations 1, 2 and 3 were 42.1,238, and 81.9 at high tide, and 47.7, 300 and 288 at low tide, respectively. In late spring 
and summer the $\mathrm{N}: \mathrm{P}$ molar ratio decreased, in parallel to the decrease in $\mathrm{N}$ and $\mathrm{P}$ and the increase in chlorophyll $a$, clearly suggesting a close relationship with the biological activity. In fact, there is a significant correlation between $\mathrm{N}: \mathrm{P}$ ratio and concentration of $\mathrm{N}$ $(\mathrm{r}=0.62, \mathrm{P}<0.001, \mathrm{n}=114)$ and between $\mathrm{N}: \mathrm{P}$ ratio and concentration of Chla $(\mathrm{r}=0.21, \mathrm{P}<0.05, \mathrm{n}=114)$.

At Station 1, the N:P molar ratio was higher than 16 (Redfield ratio) at low tide, in winter and in early spring, and slightly lower than 16 in spring/summer and autum in both tidal conditions. The seasonal evolution of the N:Si molar ratio was similar between stations, although with slightly higher values in the inner areas and during low tide. The N:Si molar ratio was higher in winter and early spring and slightly lower in mid-spring and summer in both tidal conditions, following nitrate. In fact, there is a linear relationship $(r$ $=0.63, P<0.01)$ between silicate and nitrate.

\section{Freshwater fluxes: total and specific loads}

The total loads of the rivers draining into the Ria de Aveiro were calculated as the product of the freshwater flow multiplied by the nutrient concentrations $\left(\mathrm{mmol} \mathrm{m}^{-3}\right)$ extrapolated to salinity zero. For this calculation a mean freshwater inflow of $73 \mathrm{~m}^{3} \mathrm{~s}$ ${ }^{1}$ was considered (Ferreira et al., 2003). The estimation for the total river inputs into the Ria de Aveiro were $11.3 \mathrm{~mol} \mathrm{~s}^{-1} \mathrm{~N}$ in DIN, $0.117 \mathrm{~mol} \mathrm{~s}^{-1} \mathrm{P}$ and 7.20 mol s${ }^{-1} \mathrm{Si}$, while the specific loads $\left(\mathrm{mmol} \mathrm{m} \mathrm{m}^{-2}\right.$ of drainage basin $\mathrm{d}^{-1}$ ) into the Ria de Aveiro were 316 $\mathrm{mmol} \mathrm{N} \mathrm{m} \mathrm{d}^{-2} \mathrm{~d}^{-1}, 3.26 \mathrm{mmol} \mathrm{P} \mathrm{m}^{-2} \mathrm{~d}^{-1}$ and $201 \mathrm{mmol} \mathrm{Si}$ $\mathrm{m}^{-2} \mathrm{~d}^{-1}$. The assessment of fertilisation of the Ria de Aveiro due to freshwater inputs $\left(\mathrm{mol} \mathrm{m}^{-2}\right.$ of Ria d $\left.\mathrm{d}^{-1}\right)$ was based on the fraction of the total loads $\left(\mathrm{mol} \mathrm{s}^{-1}\right)$ per area of the Ria $\left(\mathrm{m}^{2}\right)$ per day. The estimations for the fertilisation of the Ria from river inputs were $16.3 \mathrm{~mol} \mathrm{~N} \mathrm{~m}^{-2} \mathrm{~d}^{-1}, 0.168 \mathrm{~mol} \mathrm{P} \mathrm{m}^{-2} \mathrm{~d}^{-1}$ and $10.4 \mathrm{~mol}$ Si $\mathrm{m}^{-2} \mathrm{~d}^{-1}$.

\section{DISCUSSION}

Nutrient concentrations are often several times higher in rivers than in coastal seawater (Yin et al., 2001). Although it has been shown that nitrate can be essentially imported from the adjacent coastal zone (Falcão and Vale, 2003), in the Ria de Aveiro 88 to $96 \%$ of the total variance of the concentration of nitrate is explained by salinity, suggesting that the main source for this nutrient are the freshwaters inputs, which may include precipitation and freshwater flow from agricultural land draining. Moreover, the results suggest that in winter and early spring the Ria de Aveiro may be a source of nitrate input into the plume zone. Based on its conservative behaviour, the estimated concentration of nitrate in the river was $132.6 \mu \mathrm{mol} \mathrm{L} \mathrm{L}^{-1}\left(\mathrm{NO}_{3}^{-}=\right.$ -4.095 Salinity $+132.6 ; r=0.83, P<0.001, \mathrm{n}=108)$. The concentrations of nitrate followed a similar seasonal pattern and conservative behaviour to that observed in the south arm of the Mondego estuary, a well described eutrophic system (e.g. Lillebø et al., 2005). Moreover, the concentrations of nitrate at the inner stations, which were higher than those at Station 1, were within the range of the Mondego system (Lillebø et al., 2005), and in agreement with previous studies in the Ria de Aveiro (Bourge et al., 1994). However, the concentration of nitrite does not seem to depend on the freshwater inputs.

The concentration of silicate showed a similar seasonal variation and conservative behaviour to that of nitrate, with 63 to $96 \%$ of the total variance of the silicate concentration being explained by salinity. This may be due to the fact that the main supply of dissolved and particulate $\mathrm{Si}$ to rivers depends on the chemical weathering of terrestrial silicates (Ittekkot et al., 2000). The linear relationship between silicate and nitrate suggests that the system may also be a source of silicate into the plume zone in winter and early spring.

The absence of a linear relationship between ammonium and salinity and phosphate and salinity suggests that the main source of these nutrients is not dependent on the freshwater input. Both nutrients can be directly related to the biological activity and mineralisation of organic matter (e.g. PereiraFilho et al., 2001; Lillebø et al., 2004, 2005). The higher concentrations found in the inner areas, especially in spring at low tide, may be related to anthropogenic organic-rich point sources associated with mineralisation processes, which are temperaturedependent and usually enhanced when the water gets shallower (Asmus et al. 2000, Lillebø et al., 2004, 2005). Moreover, for another shallow temperate system (Sado estuary, Portugal) a linear correlation has been shown between ammonium and suspended particulate matter (Rocha et al., 1995). Mineralisation would probably be enhanced throughout spring and summer. However, possible nutrient uptake would explain the lower concentrations of these nutrients during this period. 
Chlorophyll a showed higher concentrations throughout spring and summer, with higher values in the inner areas. At Station 1, chlorophyll $a$ concentrations were higher at low tide between May and early July, suggesting an export of phytoplankton to the ocean. This hypothesis is supported by the work of Cunha et al., (2003).

The Redfield molar ratios between DIN, P and Si for phytoplankton growth are $\mathrm{Si}: \mathrm{N}: \mathrm{P}=16: 16: 1$. These ratios are merely used to define resource availability (del Amo et al., 1997) as a consequence of loading and biotic activity (e.g. Reynolds, 1999). In the Ria de Aveiro the annual variation of N:P, $\mathrm{N}$ :Si and phytoplankton biomass suggests that there is a large excess of nitrate. Applying the criteria for assessment of nutrient levels in transitional, coastal and marine waters (Crouzet et al., 1999, Table 7.1), the inner Ria shows a "bad" quality status according to the nitrogen concentrations $\left(\left[\mathrm{NO}_{2}+\mathrm{NO}_{3}\right]>16\right.$ $\mu$ mol L ${ }^{-1}$ ), while the outer Ria presents a "fair" to "poor" quality status. Nevertheless, the concentrations of nitrate were far below the threshold considered in the Nitrate Directive 91/676/EEC (Ferreira $e t$ al., 2003). The N:P ratio (several times higher than the Redfield ratio) could suggest that phytoplankton production is potentially phosphorus-limited. In fact, phosphate concentrations at the outer boundary (mean value $<0.40 \mu \mathrm{mol} \mathrm{L}^{-1}$ ) were slightly above the half-saturation constant $\left(\mathrm{K}_{\mathrm{m}}=0.1-0.2 \mu \mathrm{M}\right.$; Fisher et al., 1995, i.e. nutrient concentration at which the growth rate of a population of a species or group of species is half the maximum rate), which means that, at the seaward boundary, the availability of this nutrient was very close to the $\mathrm{P}$ requirements for planktonic populations. According to the criteria for assessment of nutrient levels in transitional, coastal and marine waters, the mean concentration of phosphate at the outer boundary has a quality status of "good" (Crouzet et al., 1999, Table 7.1). At the inner stations, phosphate concentrations were above reported half-saturation constants for $\mathrm{P}$ uptake by planktonic populations (mean values between 0.7 and $1.5 \mu \mathrm{mol} \mathrm{L}^{-1}$ ), and according to the same criteria the quality status in the shallow inner Ria ranges from "fair" to "bad" (Crouzet et al., 1999, Table 7.1). Applying the criteria proposed for the trophic classification of the Baltic Sea, including coastal waters (Wasmund et al., 2001) to the Ria under high tide conditions, the inner areas fall into the "eutrophic" status, considering the chlorophyll $a$ (annual mean concentration of Chl $a 4-10 \mathrm{mg} \mathrm{m}^{-3}$ ), and the mean winter concentration of phosphate (between 0.8 and $3.0 \mathrm{mmol} \mathrm{HPO}_{4}{ }^{2-} \mathrm{m}^{-3}$ ) and of dissolved inorganic nitrogen (between 10 and $60 \mathrm{mmol}$ DIN $\mathrm{m}^{-3}$ ). Using the same criteria, the outer boundary is classified as "mesotrophic" (annual mean concentration of Chl $a$ between 0.8 and $4 \mathrm{mg} \mathrm{m}^{-3}$; winter mean concentrations of phosphate between 0.2

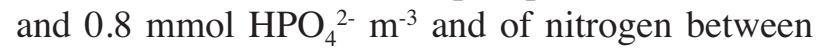
2.0 and $10 \mathrm{mmol} \mathrm{DIN} \mathrm{m}^{-3}$ ). The classification tools show that the trophic status of the inner Ria de Aveiro is clearly higher than that of the outer Ria.

At the system level, the estimations for the total river inputs into Ria de Aveiro, $11.3 \mathrm{~mol} \mathrm{~s}^{-1} \mathrm{~N}$ in DIN, $0.117 \mathrm{~mol} \mathrm{~s}^{-1} \mathrm{P}$ and $7.20 \mathrm{~mol} \mathrm{~s}^{-1} \mathrm{Si}$, were lower than the inputs from Cantabrian rivers into the Bay of Biscay reported by Prego and Vergara (1998). However, the specific loads (mmol $\mathrm{m}^{-2}$ of drainage basin $\mathrm{d}^{-1}$ ) of the rivers draining into the Ria de Aveiro were much higher than the specific loads into the drainage basin of the river Oitabén-Verdugo reported by Gago et al. (2005), which were considered high compared with other unpolluted rivers. The difference observed between the two systems may be due to the fact that, although the Ria de Aveiro receives the continental input of a higher drainage basin $\left(3097 \mathrm{~km}^{2}\right)$, its nutrient concentrations are much higher than those in the estuary of the River Oitabén-Verdugo $\left(350 \mathrm{~km}^{2}\right.$, Gago et al. (2005)). The nutrient levels recorded in the Oitabén-Verdugo estuary are one order of magnitude lower than those recorded in the polluted rivers draining into the adjacent Cantabrian sea, with comparable drainage basins and river flows (Gago et al., 2005). However, the nutrient levels in the Ria de Aveiro are of the same order of magnitude as those in the polluted rivers draining into the adjacent Cantabrian sea (Prego and Vergara, 1998).

On the basis of the application of the United States National Estuarine Eutrophication Assessment (NEEA) index, the Ria de Aveiro (Portugal) has "moderate low" overall eutrophic condition (OEC), "low" overall human influence $(\mathrm{OHI})$, and no changes were expected regarding the definition of future outlook (DFO) (Ferreira et al., 2003). Even so, in the same report, the Ria de Aveiro was classified as having a "high" level of expression for chlorophyll $a$, and the nutrient loads into the system were rated as "high". In fact, the NEEA flag "moderate low" means that the symptoms observed may be natural or that the high level of nutrient loads may cause problems despite low susceptibility (Ferreira et al., 2003). 
This also shows some vulnerability of the different methodological approaches compared in this work, which has also been highlighted by other authors (e.g. Newton et al., 2003; Lillebø et al. 2006), so their results are to be accepted with caution. Nevertheless, they demonstrate that within a system with low OEC and low susceptibility, the quality status of certain areas within the system can vary, which should be taken into consideration for specific monitoring programmes and management measurements, particularly with regard to anthropogenic point sources.

\section{ACKNOWLEDGEMENTS}

We wish to thank both anonymous reviewers for their kind and helpful contributions.

\section{REFERENCES}

Asmus, R.M., M. Sprung and H. Asmus. - 2000. Nutrient fluxes in intertidal communities of a south European lagoon (Ria Formosa) - similarities and differences with a northern Wadden sea bay (Syl-Rømø bay). Hydrobiologia, 436: 217-235.

Barroso, C.M., M.H. Moreira and P.E. Gibbs. - 2000. Comparison of imposex and intersex development in four prosobranch species for TBT monitoring of a southern European estuarine system (Ria de Aveiro, NW Portugal). Mar. Ecol. Prog. Ser., 201: 221-232.

Bourge, I., M. Frankignoulle, M.A. Esteves and A.C. Duarte. 1994. Nutrient distributions in the Ria de Aveiro, Portugal. Preliminary results. Revue Belge de Géographie, 57: 233-241.

Bricker, S.B., C.G. Clement, D.E. Pirhalla, S.P. Orlando and D.R.G. Farrow. - 1999. National Estuaryne Eutrophication Assessement: Effects of Nutrient Enrichement in the Nation's Estuaries. NOAA, National Ocean Service, Special Projects Office and the National Centers for Coastal Ocean Science. Silver Spring, MD:pp. 71

Cardoso, P., M.A. Pardal, A.I. Lillebø, S.M. Ferreira, D. Raffaelli and J.C. Marques. - 2004. Dynamic changes in seagrass assemblages under eutrophication and implications for recovery. $J$. Exp. Mar. Biol. Ecol., 302: 233-248.

Cloern, J.E. - 2001. Our evolving conceptual model of coastal eutrophication problem. Mar. Ecol. Prog. Ser., 210: 223-253.

Crouzet, P., J. Leonard, S. Nixon, Y. Rees, W. Parr, L. Laffon, J. Bøgestrand, P. Kristensen, C. Lallana, G. Izzo, T. Bokn, J.Back and T.J. Lack. - 1999. Nutrients in European ecosystems. In: N. Thyssen (ed), Environmental assessment report $n^{\circ} 4$,European Environmental Agency, pp 82. (http://reports.eea.eu.int/).

Cunha, M.A., J.M. Dias, M.A. Almeida, J.F. Lopes and F. Alcântara. - 2003. Fluxes of bacterioplankton between a tidal estuary and the sea: returning to the "Outwelling Hypothesis". Aquat. Ecol., 37: 45-54.

del Amo, Y., O. Le Pape, P. Tréguer, B. Quéguiner, A. Ménesguen, and A. Aminot. - 1997. Impacts of high-nitrate freshwater inputs on macrotidal ecosystems. I. Seasonal evolution of nutrient limitation for the diatom dominated phytoplankton of the Bay of Brest (France). Mar. Ecol. Prog. Ser., 161: 213-224.

Dolbeth, M., M.A. Pardal, A.I. Lillebø, U. Azeiteiro and J.C. Marques. - 2003. Short term and long term effects of eutrophication on the secondary production of an intertidal macrobenthic community. Mar. Biol., 143: 1229-1238.

Duarte, A.S., J.L. Pinho, M.A. Pardal, J.M. Neto, J.P. Vieira and F.S. Santos. - 2001. Effect of residence times on River Mondego estuary eutrophication vulnerability. Water Sci. Tech., 44: 329-336.
Falcão, M. and C. Vale. - 2003. Nutrient dynamics in a coastal lagoon (Ria Formosa, Portugal): The importance of lagoonsea water exchanges on the biological productivity. Cien. Mar., 29: 425-433.

Ferreira, J.G., T. Simas, A. Nobre, M.C. Silva, K. SHIfferegger and J. Lencart-Silva. - 2003. Identification of sensitive areas and vulnerable zones in transitional and coastal Portuguese systems. In: INAG- instituto da água and IMAR-Instituto do Mar (eds.), Application of the United States National Estuarine Eutrofication Assessement to the Minho, Lima, Douro, Ria de Aveiro, Mondego, Tagus, Sado, Mira, Ria Formosa and Guadiana systems, pp 53-65.

Fisher, T.R., J.M Melack, J.U. Grobbelaar and R.W. Howarth. 1995. Nutrient limitation of phytoplankton and eutrophication of inland, estuarine and marine waters. In: H. Tiessen (ed.), Phosphorous in the Global Environment, pp. 301-322. John Wiley \& Sons, Chichester.

Flindt, M.R., M.A. Pardal, A.I. Lillebø, I. Martins and J.C. Marques. - 1999. Nutrient Cycling and Plant Dynamics in Estuaries: a Brief Review. Acta Oecol. - Int. J. Ecol., 20: 237-248.

Gago, J., X.A Álvarez-Salgado, M. Nieto-Cid, S. Brea, and S. Piedracoba. - 2005. Continental inputs of C, N,P and Si species to the Ría de Vigo (NW Spain). Estuar. Coast. Shelf Sci., 65: 74-82.

Ittekkot, V., C. Humborg and P. Schafer. - 2000. Hydrological alterations and marine biogeochemistry: a silicate issue? Bioscience, 50: 776-782.

Lillebø, A.I., J.M. Neto, M.R. Flindt, J.C. Marques and M.A. Pardal. - 2004. Phosphorous dynamics in a temperate intertidal estuary. Estuar. Coast. Shelf Sci., 61: 101-109.

Lillebø, A.I., J.M. Neto, I. Martins, T. Verdelhos, S. Leston, P.G. Cardoso, S.M. Ferreira, J.C. Marques and M.A. Pardal. - 2005. Management of a shallow temperate estuary to control eutrophication: the effect of hydrodynamics on the system nutrient loading. Estuar. Coast. Shelf Sci., 65: 697-707.

Lillebø A.I., H. Teixeira, M.A. Pardal and J.C. Marques. - 2006. Applying water quality status criteria to a temperate estuary (Mondego, Portugal) before and after the mitigation measures to reduce eutrophication symptoms. Estuar. Coast. Shelf Sci., (in press).

Meeuwing, J.J. - 1999. Predicting coastal eutrophication from landuse: an empirical approach to small non-stratified estuaries. Mar. Ecol. Prog. Ser., 176: 231-241.

Moreira, M.H., H. Queiroga, M.M. Machado and M.R. Cunha. 1993. Environmental Gradients in a Southern Europe Estuarine System: Ria de Aveiro, Portugal, Implicationsfor Soft Botton Macrofauna Colonization. Neth. J. Aquatic Ecol., 27: 465-482.

Newton, A., J.D. Icely, M. Falcão, A. Nobre, J.P. Nunes, J.G. Ferreira and C. Vale. - 2003. Evaluation of eutrophication in the Ria Formosa coastal lagoon, Portugal. Cont. Shelf Res., 23: $1945-1961$

Paerl. H.W. - 2006. Assessing and managing nutrient-enhanced eutrophication in estuarine and coastal waters: Interactive effects of human and climatic perturbations. Ecol. Eng., 26: 40-54

Parsons, T.R., Y. Maita and C.M. Lally. - 1985. Pigments. Pergamon Press (ed.), A Manual of Chemical and Biological Methods for seawater analysis, pp. 101-104.

Pereira-Filho, J., C.A.F. Schettini, L. Rörig and E. Siegle. - 2001. Intratidal Variation and Net Transport of Dissolved Inorganic Nutrients, POC and Chlorophyll a in the Camboriú River Estuary, Brazil. Estuar. Coast. Shelf Sci., 53: 249-257.

Prego, R. and J. Vergara. - 1998. Nutrient fluxes to the Bay of Biscay from Cantabrian rivers (Spain). Oceanol. Acta., 21: 271-277.

Reynolds, C.S. - 1999. Non-determinism to probability, or N:P in the community ecology of phytoplankton. Arch. Hydrobiol., 146: 23-35.

Reis, A. - 1993. Ria de Aveiro - Memórias da Natureza. Câmara Municipal de Ovar.

Rocha, C., G. Cabeçadas and M.J. Brogueira. - 1995. On the importance of sediment-water Exchange processes of ammonium to primary production in shallow areas of the Sado estuary (Portugal). Neth. J. Aquatic Ecol., 29: 265-273.

Sand-Jensen, K. and J. Borum. - 1991. Interactions among phytoplankton, periphyton, and macrophytes in temperate freshwaters and estuaries. Aquat. Bot., 41: 137-175.

Tréguer, P. and P. Le Corre. - 1975. Manuel d'analyse des sels nutritifs dans l'eu de mer. Utilisation de l'Autoanalyzer Technicon II. Laboratoire d'Océanologie Chimique, Université 
de Bretagne Occidentale, Brest.

Wasmund, N., A. Andrushaitis, E. Lysiak-Pastuzak, B. MüllerKarulis, G. Nausch, T. Neumann, H. Ojaveer, I. Olenina, L.

Postel and Z. Witek. - 2001. Trophic status of the south-eastern

Baltic sea: A comparison of coastal and open areas. Estuar. Coast. Shelf Sci., 53: 849-864.

Yin, K., P. Qiam, M.C.S. Wu , J.C. Chen, L. Huang, X. Song and
W. Jian. - 2001. Shift from P to N limitation of phytoplankton growth across the Pearl River estuarine plume during summer. Mar. Ecol. Prog. Ser., 221: 17-28.

Scient ed.: J.A. Álvarez-Salgado.

Received November 14, 2005. Accepted January 29, 2007.

Published online May 23, 2007. 